\title{
WARRIORS AND CIVILIANS IN THE CRUSADE MOVEMENT. MILITARY IDENTITIES AND STATUS IN THE LIBERATION AND DEFENCE OF THE HOLY LAND (1096-1204)
}

\author{
GUERREROS Y CIVILES EN LAS CRUZADAS. \\ IDENTIDADES MILITARES Y ESTATUS EN LA \\ LIBERACIÓN Y DEFENSA DE TIERRA SANTA \\ (1096-1204)
}

Alan V. Murray

University of Leeds

\begin{abstract}
In terms of their social composition, the crusades to Palestine and Syria were unlike any other military campaigns in the Middle Ages or the modern world. The liberation and defence of the Holy Land required primarily the participation of experienced, motivated and well-equipped members of the traditional Western military classes, and the core of each crusade expedition was made up of the retinues of kings, prelates and the higher aristocracy from the countries of Europe which produced the main responses to papal calls to crusade. However, the canonical definition of crusades as penitential pilgrimages meant that most expeditions during the first century of the movement included large numbers of non-combatant men, women and children, which caused significant problems with regard to discipline and logistics. This situation only changed in the later twelfth century with a shift to the use of naval transport rather than the traditional land routes.
\end{abstract}

Keywords: Crusades, knights, military professionalism, civilians, non-combatants.

\section{RESUMEN}

Respecto a su composición social, las cruzadas a Palestina y Siria fueron diferentes a cualquier otra campaña militar medieval o moderna. La liberación y defensa de Tierra Santa requirió fundamentalmente de la participación de miembros experimentados, motivados y bien equipados pertenecientes a las clases militares tradicionales de Occidente. Del mismo modo, el núcleo de cada expedición cruzada se conformó a partir de los séquitos de los reyes, prelados y alta aristocracia de los países europeos en los que más respuestas se produjeron a las llamadas papales. Sin embargo, la definición canónica de las cruzadas como peregrinaciones penitenciales significaba que la mayoría 
de las expediciones acaecidas en el primer siglo del movimiento incluyesen grandes cifras de individuos no combatientes, incluyendo mujeres y niños, los cuales generaron importantes problemas en lo tocante a la disciplina y la logística. Esta situación solo se vio modificada a finales del siglo XII, cuando se produjo un cambio en las rutas de transporte de las terrestres a las marítimas.

Palabras clave: Cruzadas, caballeros, profesionalismo militar, civiles, no combatientes.

\section{RESUM}

\section{Guerrers i civils a les croades: identitats militars i estatus en I'alli- berament i defensa de Terra Santa (1096-1204)}

Respecte a la seva composició social, les croades a Palestina i Síria foren diferents a qualsevol altre campanya militar medieval o moderna. L'alliberament $\mathrm{i}$ defensa de Terra Santa va requerir fonamentalment la participació de membres experimentats, motivats i ben equipats pertanyents a les classes militars tradicionals d'Occident. De la mateixa manera, el nucli de cada expedició es va conformar a partir dels sèquits dels reis, prelats, i alta aristocràcia dels països europeus en els que més respostes es van produir a les crides papals. No obstant això, la definició canònica de les croades com peregrinacions penitencials significava que la majoria de les expedicions esdevingudes en el primer segle del moviment incloguessin grans xifres d'individus no combatents, incloent dones i nens, els quals van generar importants problemes respecte a la disciplina i logística. Aquesta situació es va veure modificada a finals del segle XII, quan es va produir un canvi de rutes de transport de les terrestres a les marítimes.

Paraules clau: Croades, cavallers, professionalisme militar, civils, no combatents. 


\section{Introduction: The Genesis of Crusading}

\subsection{Pope Urban II's Appeal to Knighthood}

And so I Nivello, raised in a nobility of birth which produces in many people an ignobility of mind, for the redemption of my soul and in exchange for a great sum of money given me for this, renounce for ever in favour of St Peter the oppressive behaviour resulting from a certain bad custom, handed on to me not by ancient right but from the time of my father, a man of little weight who harassed the poor with this oppression. Thereafter I constantly maintained it in an atrociously tyrannical manner. I had harshly worn down the land of St Peter, that is to say Emprainville and the places around it, in the way that had become customary, by seizing the goods of the inhabitants there. This was the rough nature of the custom. Whenever the onset of knightly ferocity stirred me up, I used to descend on the aforesaid village, taking with me a troop of my knights and a crowd of my attendants, and against nature I would make over the goods of the men of St Peter for food for my knights. ${ }^{1}$

Thus a French nobleman named Nivello expressed himself in a charter issued in 1096 in favour of the monastery of St Peter at Chartres, in which he stated his intention to join the great expedition proclaimed by Pope Urban II at the council of Clermont in Auvergne in November 1095, which was intended to liberate Jerusalem and the Holy Land from Turkish rule. The wording of the charter, with its judgemental tone, must have been formulated by the monks who undoubtedly wrote it rather than by Nivello himself, but there is no reason to doubt that his contrition for his past misdeeds was genuine; in exchange for an agreement that he and his heirs would cease despoliation of the monastery and its dependents, the monks paid him the sum of 10 pounds towards the expenses of the journey and gave smaller amounts of money to other members of his family. The circumstances described in the charter encapsulate the reasons why in attempting to raise an army for what became 
known as the First Crusade (1096-99), Urban II appealed primarily to the class of knights (milites) and by implication, their noble masters, in a manner which was intended to provide aid for Christianity in the Near East, but also to address fundamental social problems in Western Europe.

Understandably, the study of military aspects of the crusades has been primarily concerned with strategy and tactics, the course and mechanics of battles and sieges, and more recently, logistics. ${ }^{2}$ Other aspects which touch on the character of those Westerners who fought on crusades are motivation and individual (as opposed to institutional) finance. ${ }^{3}$ However, the question of military identities has been less studied, one reason that being that definitions such as "warriors" or "professionals" and "civilians" or "non-combatants" are problematic and often fluid. ${ }^{4}$ This essay will attempt to contribute to the study of military identities by exploring the social dichotomy between military elites and popular elements and the manner in which the balance between the two shifted in the course of 150 years of crusades to the Levant.

2 Bibliography on these topics is extensive. Some of the most fundamental studies are: SMAIL, R.C. (1995): Crusading Warfare, 1097-1 193, 2nd edn. ed. C. MARSHAL. Cambridge, Cambridge University Press; FRANCE, J. (1994): Victory in the East: A Military History of the First Crusade. Cambridge, Cambridge University Press; FRANCE, J. (1999): Western Warfare in the Age of the Crusades, 1000-1300. London, UCL; FRANCE, J. (2005): "Crusading Warfare". NICHOLSON, H. (ed.), Palgrave Advances in the Crusades. Basingstoke, Palgrave Macmillan; FRANCE, J. (2006): "Thinking about Crusader Strategy". CHRISTIE, N. and YAZIGI, M. (eds.), Noble Ideals and Bloody Realities: Warfare in the Middle Ages. Leiden, Brill, pp. 75-96; FRANCE, J. (2011): "Warfare in the Mediterranean Region in the Age of the Crusades, 1095-1291: A Clash of Contrasts". KOSTICK, C. (ed.), The Crusades and the Near East. Abingdon: Routledge, pp. 9-26; PRYOR, J. (1992): Geography, Technology and War: Studies in the Maritime History of the Mediterranean, 649-1571. Cambridge, Cambridge University Press; PRYOR, J. (ed.) (2006); Logistics of Warfare in the Age of the Crusades. Aldershot, Ashgate; TYERMAN, C. (2015): How to Plan a Crusade: Reason and Religious War in the High Middle Ages. London, Allen Lane, 2015. Other key works are cited at appropriate points in the discussion below.

3 CONSTABLE, G. (1982): "The Financing of the Crusades in the Twelfth Century". KEDAR, B.Z., MAYER, H.E. and SMAIL, R.C. (eds.), Outremer: Studies in the History of the Crusading Kingdom of Jerusalem. Jerusalem, Yad Izhak Ben-Zvi Institute, pp. 64-88; RILEY-SMITH, J. (1986): The First Crusade and the Idea of Crusading. London, Athlone; RILEY-SMITH, J. (1995): "Early Crusaders and the Costs of Crusading, 1095-1130". GOODICH, M., MENACHE, S. and SCHEIN, S. (eds.), Cross Cultural Convergences in the Crusader Period. New York, Peter Lang, pp. 237-258; RILEY-SMITH, J. (1997): The First Crusaders, 1095-1 131. Cambridge, Cambridge University Press.

4 PORGES, W. (1946): "The Clergy, the Poor and the Non-Combatants on the First Crusade", Speculum, n ${ }^{\circ} 21$, pp. 1-23; KOSTICK, C. (2013): "Courage and Cowardice in the First Crusade, 1096-1099", War in History, n 20, pp. 32-49. 
In what follows the terms "warriors" and "soldiers" are employed to denote people who had received training in fighting techniques and discipline, and who earned their living primarily by military activity. The term "civilians" is used to denote those who did not engage in military activities in the course of their everyday lives, at least up to the point that they joined forces bound for the East. However, it shall become evident that these categories did not remain hard and fast during the course of crusade expeditions, whose character often obscured distinctions which might have been clear cut in other contexts. Further clarification will be given in the course of more detailed discussion.

Urban's call to crusade at Clermont came in response to appeals from the Byzantine emperor, Alexios I Komnenos, who wished to stem the Turkish advance into Syria and Asia Minor after the collapse of Byzantine resistance in the wake of the defeat of his predecessor Romanos IV Diogenes at the hands of the Seljuk sultan Alp Arslan at Manzikert in eastern Anatolia in 1071. Alexios had already employed Western knights in his service, both individually and in regiments, such as a contingent of 500 knights sent by the count of Flanders. These men constituted mercenaries in one of the most generally accepted senses of the word, in that they were soldiers who had left their home country to serve a foreign power for pay. Such a basis for service was quite common in the Byzantine army, which employed Varangians, Slavs, Armenians, Turkic peoples and Westerners (generally known as Franks) alongside native Greeks, and this form of military service was much more similar to modern military practice than the armed forces of contemporary Western Europe, which were largely recruited on the basis of feudo-vassalic obligations. ${ }^{5}$ Evidently Alexios hoped for much greater numbers of such experienced soldiers who would fight alongside the Byzantine army, but the use of mercenaries, in the sense just defined, proved to be practically non-existent in the course of the crusades to the Holy Land. ${ }^{6}$ The Western perspective was different. Pope Urban must have realised that aid for Byzantium probably had only a limited appeal among Western Christians, and so he coupled his call to crusade with the aim of freeing the Holy Land and its Christian population from Turkish rule, thus combining the idea of holy war with pilgrimage to the most sacred sites in the Christian faith.

BIRKENMEIER, J. (2002): The Development of the Komnenian Army, 1081-1180. Leiden, Brill, pp. 77-158.

SHEPARD, J. (1997): "Cross-Purposes: Alexius Comnenus and the First Crusade". PHILLIPS, J. (ed.), The First Crusade: Origins and Impact. Manchester, Manchester University Press, pp. 107. 129. For a recent discussion of mercenaries see: FRANCE, J. (ed.) (2008): Mercenaries and Paid Men: The Mercenary Identity in the Middle Ages. Leiden, Brill. 
The response which it brought forth gave rise to a form of warfare which was completely new in terms of the social makeup of those who volunteered to fight in it.

It is clear from all contemporary accounts of the council of Clermont that in his appeal, Urban was addressing himself to the knightly class of Western Europe. We must remember that at this time the status of knight was not yet imbued with the ideology and ethos of the cultural phenomenon that in retrospect came to be called "chivalry". This new idea of chivalry began to develop in the later twelfth century under the influence of the Arthurian romances of Chrétien de Troyes and his successors as well as religious reformers, so that by the thirteenth century most members of the higher nobility and royal families were happy to be described as knights and undergo knighting ceremonies, even though there was a vast social gulf between a count or duke and a simple knight in possession of a small country estate or serving in a castle garrison. What was happening here was a development of the concept of knighthood, which was being extended far beyond its original meaning. At the time of the council of Clermont, things were very different, however. Knights formed a military and managerial caste in the service of kings, bishops, dukes, counts and lords, who employed them in numbers ranging from dozens (as was probably the case with the Frenchman Nivello) to many hundreds, as in the cases of the princes of the Holy Roman empire and the great vassals of the kings of France. Fighting on horseback, armed with lance and sword and protected by a hauberk (coat of mail), helmet and shield, the knight was the dominant element in Western military forces in the eleventh and twelfth centuries. ${ }^{7}$

Knights served in all manner of conflicts, ranging from small-scale raiding to sieges and major wars. As a social group which exercised a near monopoly of violence, knights also had a propensity to feuding amongst themselves and to despoiling easy targets. In most of these cases it was institutions or groups which rarely had the means to defend themselves (such as monasteries or peasants) that suffered the most. Nivello and his followers clearly had military experience that would make them useful on crusade, but according

7 BUMKE, J. (1982): The Concept of Knighthood in the Middle Ages. New York, AMS Press; FLORI, J. (1998): Chevaliers et chevalerie au Moyen Age. Paris, Hachette. The chronicler Gilbert of Mons gives credible figures for the knightly retinues of princes of the Holy Roman empire in the twelfth century, ranging from 500 each for the duke of Austria and the abbot of Fulda to 1000 or more for the count palatine of the Rhine, the landgrave of Thuringia and the archbishop of Cologne. See Gilbert of Mons, Chronicle of Hainaut, trans. L. NAPRAN (Woodbridge, Boydell Press, 2005), esp. pp. 87-88. 
to his confession, they had regularly plundered the estates and dependents of the monastery of St Peter. It was Pope Urban's idea to channel and divert this destructive and senseless violence towards a more laudable and deserving purpose by recruiting the knights of the West as the principal force in his expedition to recover the Holy Land. As the monk Robert of Rheims phrased it in his account of Urban's speech at Clermont:

"Let those", he [Urban] said, "who are accustomed wantonly to wage private war against the faithful march upon the infidels in a war which should be begun now and be finished in victory. Let those who have long been robbers now be soldiers of Christ. Let those who once fought against brothers and relatives now rightfully fight against barbarians. Let those who have been hirelings for a few pieces of silver now attain an eternal reward. Let those who have been exhausting themselves to the detriment of body and soul now labour for a double glory". ${ }^{8}$

Urban envisaged the participation of a number of clerics to provide religious leadership and spiritual guidance. They included his chosen leader, Adhemar, bishop of Le Puy, and a number of other bishops (especially from southern France). However, he expected the bulk of the forthcoming crusade to be made up of secular lords and their entourages of knights, a combination for which modern scholarship has devised the overarching term armsbearers. In a letter to the monks of Vallombrosa sent on 7 October 1096, Urban stated that he had intended to persuade knights to join the expedition, but that he was concerned that "the wrong kind of person" - meaning priests and monks - wanted to set out with them. ${ }^{9}$ In practice neither Urban's commands nor monastic discipline prevented a number of priests, monks and even nuns joining the expedition, but these came to be vastly outnumbered by lay people from beyond the noble and knightly warrior classes.

For the church, the ideal way to fight for the faith had been to live as a monk, a lifestyle that was ill-suited to the majority of believers. What was new about Urban's plan for the crusade was that anyone could fight for the faith in a real sense. Knights who had been condemned by the church for their violent lifestyles could now deploy their military skills in the service of the faith, and gain spiritual benefits in doing so. However, in practice it proved impossible to restrict participation to knights. Urban proclaimed the expedition as a pilgrimage, an institution which had traditionally been 
open to all classes. As the primary incentive, the Pope offered a remission of sins to all who went to the Holy Sepulchre, the traditional site of Christ's burial, death and Resurrection. The precise nature of this indulgence has been much debated by historians, but the important thing is that thousands of people regarded it as an unrepeatable offer in which they could rid themselves of the consequences of $\sin$ in the afterlife. The prospect of this wonderful spiritual bargain meant that members of all social classes joined up by taking the sign of the cross: men, women and children; old and young; rich and poor; free and unfree; townspeople and peasants; laypeople, clerics and monks. ${ }^{10}$

\subsection{Princes' Crusades and Popular Crusades}

The practicalities of recruitment of crusaders over most of France, the Low Countries, western Germany, northern Italy and the British Isles meant that the large number of crusaders who responded to Urban's appeal formed themselves into over a dozen different contingents which travelled separately to the East, but it is important to recognise that these can be regarded as belonging to two distinctive types of units in terms of their composition and leadership.

The majority of crusaders spent many months preparing for their journey, using the time following the council of Clermont to raise the necessary finance, put their affairs in order, and make contact with potential companions, with the aim of leaving on or near the official departure date of the Feast of the Assumption (15 August 1096). Command in crusade armies was based on social rank rather than military ability, although the nature of Western society meant that most of the great lords who figured as commanders already had experience of warfare. This meant that most crusaders, whether singly or (more probably) in small groups of kinsfolk, acquaintances or fellow workers, coalesced around a number of great lords, whose status meant that their leadership was necessarily accepted by those who aimed to travel with them: Raymond of Saint-Giles, count of Toulouse; Godfrey of Bouillon, duke of Lower Lotharingia; Stephen-Henry, count of Blois, and Hugh, count of Vermandois; Robert II, count of Flanders, and Robert Curthose,

10 KOSTICK, C. (2008): The Social Structure of the First Crusade. Leiden, Brill; MURRAY, A.V. (2012): "Sex, Death and the Problem of Single Women in the Armies of the First Crusade". GERTWAGEN, R. and JEFFREYS, E. (eds.), Shipping, Trade and Crusade in the Medieval Mediterranean: Studies in Honour of John Pryor. Farnham, Ashgate, pp. 255-270. 
duke of Normandy. ${ }^{11}$ The contingents led by these lords are now generally referred to as "princes' crusades". In their composition and recruitment, each of these armies (each generally referred to in the sources by the Latin noun exercitus) can be thought of a series of concentric circles. The central element was the princely household. Beyond this were various lords and knights who were connected with the leader by ties of kinship or vassalage, together with their own dependents, while on the periphery were others whose ties were much looser, being based on regional identity or linguistic affiliation. ${ }^{12}$ This scheme can be illustrated in terms of the composition of the army of Godfrey of Bouillon. At its core were Godfrey himself, his brother Baldwin of Boulogne and Baldwin's wife Godevere, along with household officials of knightly rank, who included a seneschal, a butler, and chamberlain, while Baldwin had a secretary who was probably a cleric. This central element also included a number of Bullonienses, that is, knights who held fiefs in Godfrey's allodial territory of Bouillon in the Ardennes, who included the castellan of Bouillon, one Heribrand. Beyond them were a number of lords from neighbouring areas of Lower Lotharingia and the northern part of the kingdom of France, many of whom were linked to Godfrey and Baldwin by ties of kinship: Warner, count of Grez; Cuno, count of Montaigu, and his sons Gozelo and Lambert; Henry and Godfrey of Esch-sur-la-Sûre; Baldwin of Mons, count of Hainaut; Dudo, lord of Cons-la-Grandville; Peter of Dampierre, count of Astenois, and his brother Rainald, count of Toul; and Baldwin, lord of Bourcq. Each of these lords must have had his own retinue of knights, grooms and other servants. Beyond them was a less easily discernable group of laymen and clerics, many of them from urban environments, who included Adalbero of Luxembourg, archdeacon of Metz, and others from the region, as well as those who joined Godfrey from areas that his army passed through on its journey to the East, such as Reinhold of Helmarshausen in Hesse, or Hartmann, count of Dillingen and Kyburg in Upper Swabia. ${ }^{13}$

11 The Italian-Norman leader Bohemund later led a contingent of Normans and Lombards, but I have argued that his decision to join the crusade was largely opportunistic and occurred only after the contingents from north of the Alps were passing through Italy. See: MURRAY, A.V. (2015): "The Enemy Within: Bohemond, Byzantium and the Subversion of the First Crusade". HURLOCK, K. and OLDFIELD, P. (eds.), Crusading and Pilgrimage in the Norman World. Woodbridge, Boydell \& Brewer, pp. 31-47.

12 MURRAY, A.V. (2011): "National Identity, Language and Conflict in the Crusades to the Holy Land, 1096-1 192". KOSTICK, The Crusades and the Near East, pp. 107-130.

13 MURRAY, A.V. (1992): "The Army of Godfrey of Bouillon, 1096-1099: Structure and Dynamics of a Contingent on the First Crusade". Revue Belge de Philologie et d'Histoire, $n^{\circ} 70, \mathrm{pp}$. 301-329. 
Yet long before the princes' crusades set off, other groups were already on the move which were more popular in composition and less hierarchical in their organisation. Their leadership was not based on status and authority, as in the case of the princes' expeditions, but on the personal charisma and promises of those who led them. The wandering preacher Peter the Hermit attracted numerous followers from central and northern France, primarily though the effectiveness of his preaching, and the priest Gottschalk had a similar response in the Rhineland. Others who responded to appeals were more obviously driven by cupidity. Emicho, count of Flonheim, collected a large number of followers from the central Rhineland, who combined with other crusaders coming from the West to attack and despoil the Jews of Mainz. ${ }^{14}$ These and other similarly organised groups were at one time referred to as "Peasants' Crusades", although this designation has now largely been set aside as misleading. Nevertheless, they seem to have included far fewer members of the noble and knightly classes than the princes' expeditions; indeed, it is scarcely conceivable that members of the higher nobility, who were used to exercising command, would have been willing to accept the leadership of simple priests or preachers such as Peter the Hermit. Peter's army eventually absorbed other groups from the lle-deFrance, northern France and western Germany, and while these included knights such as Walter Sans-Avoir (from Boissy-sans-Avoir near Paris) and others from his kin group, the relative paucity of named individuals in the sources suggests that it predominantly consisted of townspeople, peasants and other country dwellers. ${ }^{15}$

Most of these popular groups, as well as others from northern Italy, were already in motion by the spring of 1096. Since their participants were generally poorer than those of the princes' crusades and had spent little time in preparation, they were obliged to recruit additional members and secure funds and provisions on the move as they marched east, through a combination of appeals to charity, plundering and extortion, particularly through despoliation of the Jewish communities of Germany and Bohemia. The lawlessness and indiscipline which they exhibited resulted in most of them being violently dispersed by German or Hungarian authorities. Only a minority reached Constantinople and crossed into Asia Minor, but after a

14 FLORI, J. (1999): Pierre l'Ermite et la Première Croisade. Paris, Fayard; MÖHRING, H. (1992): "Graf Emicho und die Judenverfolgungen von 1096". Rheinische Vierteliahrsblätter, n 56, pp. 97-111.

15 Albert of Aachen, Historia lerosolimitana: History of the Journey to Jerusalem, ed. and trans. S. B. EDGINGTON (Oxford, Oxford University Press, 2007), pp. 1-5, 8-17, 44-53. 
crushing defeat by the Turks of the sultanate of Rūm in the autumn of 1096, the pitiful survivors had little choice but to attach themselves to the princes' expeditions.

\subsection{Problems of Definition: Professionals and Civilians in the First Crusade}

The diverse contingents which assembled on the Asian shore and marched towards Nicaea in early 1097 numbered in total perhaps some 50,000 60,000 men, women and children. ${ }^{16}$ The vast majority of them (as well as those in subsequent expeditions) were volunteers, in the sense that they had voluntarily taken public vows to travel to Jerusalem, reflected in the sign of the cross worn on their clothing. However, we should remember that in this labour-intensive age not only nobles, but many others of much humbler status could afford to maintain personal servants, who may well have had little choice but to accompany their masters. In terms of their experience of war, participants can be roughly divided into two categories. On the one hand were the armsbearers, that is, members of the nobility and their retinues of mounted knights. Most of these would have needed grooms, while the wealthier ones were probably accompanied by other specialists such as armourers, farriers and falconers, as well as contingents of footsoldiers with varying degrees of protective equipment. On the other hand there were significant numbers of peasants, labourers, artisans, domestic servants, as well as clerics and other religious. These can be classified - for want of a better word - as civilians, meaning that they had no experience of warfare in their lives prior to their participation in a crusade, except perhaps, that some of them may have previously been on the receiving end of knightly violence.

It is difficult to map such categories onto classifications such as professionals, mercenaries or non-combatants, whose definitions have essentially been driven by military experience in the post-medieval world, and in more recent times, by laws and conventions. Since around the late fifteenth or sixteenth centuries, professional soldiers can be defined by a number of characteristics which have by and large been maintained up to the present. At its most basic, this form of professionalism required that its practitioners had to undergo training in using weapons and moving in formation on the battlefield, a circumstance which presupposes the existence of a recognised system of drill and commands. To this we can add the acceptance of a hierarchy of military ranks and uniforms (at least within single units). Several of these features were already present among the landsknechts and Swiss 
pikemen and halberdiers of the later Middle Ages, as well as the Spanish tercios of the sixteenth century, and they continued to be characteristic of modern armies, whether these were primarily formed from volunteers (as in the British and French armies of the eighteenth century) or conscripts, as in the military systems of eighteenth-century Prussia and the national armies of most of continental Europe in the period after the French Revolution.

It is no coincidence that all of these modern examples related primarily to footsoldiers, who required drill and ordered formations to function effectively, but who also needed to be more amenable to such discipline than were cavalrymen. Armies of the late eleventh and twelfth centuries were dominated by mounted knights, but there were few formal methods of training that resembled those of modern forces. The most essential attribute for a knight was to be able to ride a horse from an early age and wield spear, sword and shield while doing so. The effectiveness of the charge depended on maintaining a tight formation with knights riding knee to knee, and although some had the opportunity to practice manoeuvres in tourneys, most knights would have learned to fight in formation through real experience and practice.

The distinction between combatants and civilians which prevailed at the beginning of the First Crusade became progressively blurred by conditions which developed in the course of the long march to Jerusalem. The status of knights depended not only on their military experience and skills, but also on their possession of horses and equipment, which enabled them to fight in an effective manner. Most military conflicts in the West at this time were relatively limited in their objectives and thus restricted in time. By contrast, the duration of the First Crusade - from departure in August 1096 to the capture of Jerusalem in July 1099 - had effects which all but the most seasoned participants would have rarely experienced in campaigning in their home countries. During the crossing of the Anatolian plateau, many horses died either as a result of starvation and thirst or from being slaughtered for food by the equally starving crusaders. During the privation of the siege of Antioch, which lasted through the winter and spring of 1097 . 1098, many crusaders sold their possessions to buy food. Horses, and armour and weapons that had been captured, lost or became unusable were difficult to replace many thousands of kilometres away from home, which affected status as well as the ability to fight. One vivid example can illustrate this phenomenon. During the siege of Nicaea (1097), Hartmann, count of Dillingen and Kyburg, had sufficient spare funds to part finance the construction of a siege engine. Yet within a year he had sold his horse and armour, and was riding an ass and fighting with captured Turkish weapons. He was dependent on Godfrey of Bovillon for a daily ration of food, which 
meant that he was probably no longer able to maintain the retinue that must have originally accompanied him. One of the richest men in southern Germany had been reduced to the status of a simple footsoldier, and many other lords and knights were in the position of dependents of the princes, who were better placed to secure forage and tribute by virtue of their role as field commanders and organisers. ${ }^{17}$

At the same time the requirements placed on civilians meant that many of them were gradually being transformed into soldiers. The crusade army was divided into a number of contingents, each led by one of the princes, which marched separately, and each of these units seems to have organised its own foraging and provisioning. This meant that civilians had little choice but to accept the orders and discipline imposed by those in command. It is difficult to train an adult civilian to fight on horseback, which is why knights learned to ride while still in their youth, but a civilian could be made into an infantry soldier given the requirements of the campaign. The crusaders fought pitched battles against highly mobile Turkish horsemen at Dorylaion (July 1097), Albara (December 1097) and at Antioch (February and June 1098), who were more mobile than the crusader cavalry. However, in most of these cases a significant role was played by the crusader infantry, whose effectiveness increased progressively. Yet a greater amount of time was spent in lengthy sieges of a succession of Muslim-held cities: Nicaea (MayJune 1097), Antioch (October 1097 - June 1098), Ma'arrat al-Numan (November-December 1098), 'Akkar (April-May 1099), and Jerusalem (June-July 1099). In these situations knights had to fight dismounted, and infantrymen had to carry out a wide range of tasks: going on foraging parties, sourcing building materials and constructing ladders and other siege equipment, doing sentry duty and guarding prisoners, and in many cases, taking part in assaults. This all meant that by the summer of 1099, when Jerusalem was finally taken, most of the originally civilian crusaders had probably learned to wield weapons, follow orders and maintain disciple, and keep formation where required. It was this cohesion acquired over several years that enabled the crusader army, despite being much reduced in numbers, to win its final victory over a numerically superior Fātimid army on the coastal plain outside Ascalon in August 1099. ${ }^{18}$

17 Albert of Aachen, Historia lerosolimitana, pp. 332-334; MURRAY, A.V. (2006): "Money and Logistics in the Armies of the First Crusade: Coinage, Bullion, Service and Supply, 1096-99". PRYOR, Logistics of Warfare, pp. 229-249.

18 MURRAY, A.V. (2017): "A Race against Time - A Fight to the Death: Combatants and Civilians in the Siege and Capture of Jerusalem". DOWDALL, A. and HOME, J. (eds.), Civilians under Siege from Sarajevo to Troy. Basingstoke, Palgrave Macmillan, forthcoming. 


\section{The Defence of the Holy Land}

\subsection{The Frankish Hosts}

The majority of crusaders probably returned to the West in the summer of 1099, but those lords and knights who remained went on to constitute the military and administrative classes of the four new principalities established by the crusade: the county of Edessa, the principality of Antioch, the county of Tripoli and the kingdom of Jerusalem, known collectively to Western Christians as Outremer. ${ }^{19}$ It is also likely - although difficult to demonstrate with certainty - that many of those who had fought in the crusade as footsoldiers remained to follow military professions in the new homeland.

The opponents of the Frankish states of Outremer were mostly Turkish (or in the case of Saladin, Kurdish) rulers or warlords. The main element in their military forces were professional mounted soldiers (known as mamlüks or ghülams), recruited mostly from Turks or Kurds, but with small numbers from other ethnic groups; each was normally equipped with a mail coat, spear, sword, shield and the composite bow. This core force was usually augmented by nomadic Türkmen tribesmen, fighting in a similar manner but with less armour, while Turkish leaders who controlled major cities such as Aleppo or Damascus could also deploy militias of footsoldiers drawn from the predominantly Arab urban populations. ${ }^{20}$ By contrast, the Fātimid caliphs of Egypt employed multi-ethnic forces which proved much less effective against the Franks; these were disbanded and replaced by mamlüks when Saladin overthrew the caliphate in 1171 . The key element in Frankish armies was the knights, who were used to deliver a devastating charge, a tactic which the Muslim forces feared and did not try to replicate themselves. The main Turkish tactic was to move close and use archery to wear down the Frankish troops; feigned retreats were also used in the hope of breaking up Frankish formations. This meant that the Franks had to employ large numbers of trained infantry to hold the army's position and protect the knights and their

19 RICHARD, J. (1989): "La noblesse de Terre Sainte (1097-1 187". Arquivos do Centro cultural português, $n^{\circ} 26$, pp. 321-336; MURRAY, A.V. (1989): "The Origins of the Frankish Nobility of the Kingdom of Jerusalem, 1100-1 $118^{\prime \prime}$. Mediterranean Historical Review, $\mathrm{n}^{\circ}$ 4, pp. 281-300; MURRAY, A.V. (1997): "How Norman was the Principality of Antioch? Prolegomena to a Study of the Origins of the Nobility of a Crusader State". KEATS-ROHAN, K.S.B. (ed.), Family Trees and the Roots of Politics: The Prosopography of Britain and France from the Tenth to the Twelfth Century. Woodbridge, Boydell \& Brewer, pp. 349-359; MURRAY, A.V. (2009): "Norman Settlement in the Latin Kingdom of Jerusalem, 1099-1 131". Archivio Normanno-Svevo, n 1, pp. 61-85.

20 HILLENBRAND, C. (1999): The Crusades: Islamic Perspectives. Edinburgh, Edinburgh University Press, pp. $431-467$. 
valuable warhorses until the point that the charge could be unleashed.

A list detailing the military service of the kingdom of Jerusalem shortly before its great defeat by Saladin at the battle of Hattin in 1187 was preserved in the Livre des Assises, a treatise of laws and customs compiled by John of Ibelin, count of Jaffa (d. 1266). It gives the total service available to the king as some 675 knights and 5025 sergeants. ${ }^{21}$ The sergeants were provided by the bishoprics and the urban communities and were most probably footsoldiers, although some may have served on horseback in lighter equipment than the knights. It is likely that the sergeants were full-time professional soldiers, although we cannot exclude the possibility that they were members of the burgess class who were obliged to perform military service as necessity dictated as a condition of their tenures. Experts have argued that the number of knights given by John of Ibelin was considerably lower than the size of the greatest Frankish armies would suggest, and that his figures represented only the service that lords were obliged to provide to the Crown. Thus the count of Jaffa and the lords of Tiberias and Sidon each owed the service of 100 knights, with smaller lordships providing lesser numbers. In actual fact many lords, especially those who held fiefs in frontier areas, probably enfeoffed greater numbers than their own obligations demanded, ${ }^{22}$ which meant that more soldiers were available than were enumerated in the Livre des Assises. A large number of knights were also maintained directly by the Crown through an institution known as the money-fief (French: fief-rente). These men did not hold landed fiefs, but were remunerated directly in cash out of royal revenues. Palestine was a money economy, and there was generally more coin in circulation than in Western Europe. The money-fiefs in Palestine may have originated as a result of tribute paid by Muslim-held cities to Frankish rulers, who used this income to remunerate many of their vassals. All of the Muslim cities in Palestine were in Frankish hands by 1125 except for Ascalon (which fell in 1153), and from this time most of the money-fiefs were probably paid out of customs revenues accruing to the Crown in the demesne cities of Acre and Tyre, and to a lesser extent, other revenues in territories of Nablus and the city of Jerusalem. ${ }^{23}$

21 EDBURY, P.W. (1997): John of Ibelin and the Kingdom of Jerusalem. Woodbridge, Boydell, pp. $118-154$.

22 EDBURY: John of Ibelin, p. 131; FRANCE, J. (2000): "Crusading Warfare and its Adaptation to Eastern Conditions in the Twelffh Century". Mediterranean Historical Review, n 15, pp. 49-56.

23 MURRAY, A.V. (2008): "The Origin of Money-Fiefs in the Latin Kingdom of Jerusalem". FRANCE, Mercenaries and Paid Men, pp. 275-286. 
The nobles and knights of Outremer formed a hereditary caste of European origin, although there was probably less of a divide between the two groups than in the West; because of a general shortage of manpower several relatively lowly or otherwise obscure knights were able to acquire fairly important lordships, especially in the first few decades after the First Crusade. Another important difference was that in the West the service of vassals to their lords was becoming limited by custom to 40 days in the year, but in Jerusalem service in defence of the kingdom was unlimited, and the same probably applied in the other states. By contrast, when kings such as Amalric (1 163-1 174) campaigned in Egypt, they were obliged to offer their vassals financial inducements to take part in expeditions outside the kingdom.

Much less is known about the forces of the northern states of Antioch, Tripoli and Edessa (especially since the last named had fallen to the Turks by 1150 , leaving few surviving sources). However, one significant difference compared to the kingdom of Jerusalem is that the Franks of Syria made extensive use of native Christians in their armies. Unlike conditions in Palestine, where native Christians had lost their upper classes in the course of Muslim invasions, the Armenians of Upper Mesopotamia and Cilicia and the Greeks of Syria still had a class of nobles, chieftains and warriors, many of whom served the Franks as soldiers and administrators. Thus one Euterpius, described as a 'most worthy knight in physical and mental strife', was killed fighting against the Turks at the battle known as the Field of Blood (Ager Sanguinis) in 1119 . This name is undoubtedly of Greek origin and is unknown among Western populations. ${ }^{24}$ Vassals of the Mazoir lords of Margat, named in a charter of Prince Bohemund III of Antioch dating from 1186, include two men named Amelin and Baldwin who were clearly Franks, but also two Easterners with Greek names, George and Theodore. The fact that they are explicitly described as knights and also given the title dominus clearly indicates that they were part of the Mazoir family's military retinue and were more than simple footsoldiers. ${ }^{25}$ Similarly, the Maronites of the Lebanon mountains had maintained military traditions in centuries of resistance to Muslim invaders, and provided soldiers (notably archers) to the counts of Tripoli. ${ }^{26}$ Both Antioch and Jerusalem employed considerable

24 Walter the Chancellor, Galterii Cancelarii Bella Antiochena, ed. H. HAGENMEYER (Innsbruck, Wagner, 1896), p. 90.

25 RÖHRICHT, R. (ed.), Regesta Regni Hierosolymitani, 2 vols. (Innsbruck, Wagner, 1893-1904), no. 649. Another of this group, Dominus Zacharias, may also have been an Eastern Christian.

26 SALIBI, K.S. (1957): "The Maronites of Lebanon under Frankish and Mamluk Rule (1099-1516)". Arabica, $n^{\circ} 4$, pp. 280-303. 
numbers of light cavalry known as Turcopoles, a name deriving from the Greek точркотоићо . This term was used to denote Turkish mercenaries in Byzantine service, but in Outremer it is unclear whether these were really Turks, or were possibly Eastern Christians fighting in the Turkish manner. ${ }^{27} \mathrm{~A}$ private charter issued in 1180 gives a list of witnesses described as Turcopuli, one of whom is named as Gaifredus Baptizatus. The second element of this name suggests that he had converted to Christianity, and had taken the Western name Gaifredus (Geoffrey) on that occasion. The names Godfrey and Gormund are clearly Western in origin, while the names Peter, John and Andrew were popular among both Western and Eastern Christians. The fact that one is named along with his son indicates that the Turcopoles could also be a hereditary profession, although the evidence of names appearing in this charter suggests that they were a fairly diverse group. ${ }^{28}$

The principalities of Outremer were perennially short of manpower. Even when garrisons in castles and towns had been reduced to an absolute minimum, each state could only put a single host into the field, which was invariably smaller than invading Muslim forces. Commanders were thus often reluctant to risk this army, since if it was defeated - as happened against Saladin at the battle of Hattin in 1187 - there would be no sizeable forces left to combat the Muslims. In order to increase available numbers, rulers and holders of lordships seem to have augmented their vassals by employing knights who served purely for pay. The notorious Rainald of Châtillon, who rose to become prince of Antioch and later lord of Transjordan, and died at the hands of Saladin after being captured at Hattin, first appeared in the Holy Land holding a stipendium (a stipend or salary) from King Baldwin III of Jerusalem (1 145-1 163) at the siege of Ascalon in 1153. Rainald does not seem to have taken a crusade vow, but left France and took service with the king of Jerusalem for regular pay. By most definitions, he was a mercenary. ${ }^{29}$ This category of hired men becomes clearer in a charter issued in 1158 by Amalric, then count of Ascalon and later king of Jerusalem, which was witnessed by three groups of men of knightly rank. They are respective-

27 Walter the Chancellor, Galterii Cancelarii Bella Antiochena, pp. 74, 84, 88; RICHARD, J. (1986): "Les Turcoples au service des royaumes de Jérusalem et de Chypre: Musulmans convertis ou chrétiens orientaux?". Revue des études islamiques, n 54, pp. 259-270.

28 RÖHRICHT, Regesta Regni Hierosolymitani, no. 594: Gaifredus Baptizatus, Durantus Scutifer, Petrus, filius ejus, magister Godofredus, Petrus de Capharset, Petrus Lorgius, Arnulfus, Stephanus Rex, Silvester de Sapharia, Gormundus, Andreas, Bonettus Salvagius, Johannes Sansan.

29 Guillaume de Tyre, Chronique, ed. R.B.C. HUYGENS, Corpus Christianorum Continuatio Mediaevalis 63-63A, 2 vols. (Turnhout, Brepols, 1986), p. 790. 
ly described by Amalric as homines mei, meaning his own vassals in the county of Ascalon; homines regis, that is vassals of his brother Baldwin III; and finally stipendiarii mei, who must thus have been mercenaries serving Amalric for pay, rather than holding fiefs like the homines. ${ }^{30}$

\subsection{The Military Monastic Orders}

It was the requirements of the defence of the Holy Land that brought forth one of the most novel and distinctive types of warrior in European history. In 1119-1120 a number of knights living in Palestine dedicated themselves to the protection of pilgrims travelling between their points of arrival on the coast and the holy sites in and around Jerusalem. By 1129 the Templars, as they became known, had been granted a rule, making them into a religious organisation similar to existing orders of monks, but what was revolutionary was that they were permitted and indeed, expected to fight for the Christian faith. In categorising the knight brethren of the military order it is difficult to apply modern concepts of professionalism. We tend to think of a professional soldier as someone who has made a career of service in the military, and while the Templar (and members of other orders) dedicated his life to the knighthood of Christ by fighting against the enemies of Christianity, he combined this service with the lifestyle of a monk. Traditional monastic orders were organised around the celebration of the liturgy, prayer, contemplation and manual work, a combination which did not necessarily appeal to men from the knightly classes who had been brought up to ride, fight and hunt; membership of the Order of the Temple allowed them to combine a religious vocation with a military lifestyle which would have been familiar to them. Thus Templars profited from their service not in material, but in spiritual terms, yet despite their formal status as monks they were probably the most dedicated form of soldier in medieval Christendom. Indeed, a Templar made a profession at the time of his entry into the order, when he took vows of poverty, chastity and obedience. He was subjected to severe forms of discipline, both on campaign and in everyday life, with punishments for infringements of vows as well as for actions that threatened the cohesion of the order's units in wartime. The fact that this quite innovative organisational form was accepted by the papacy and the wider church owed a great deal to the support of the influential Cistercian theologian Bernard of Clairvaux, notably in his treatise written in its support, De laude novae militiae (In Praise of New Knighthood). What Bernard meant by "new knighthood"

30 MAYER, H.E. (ed.), Die Urkunden der lateinischen Könige von Jerusalem, 4 vols. (Hannover, Hahnsche Buchhandlung, 2010), 1, no. 298. 
was a pure form of knightly life in the service of the faith, in contrast to what he perceived as the older, sinful and destructive lifestyle of secular knights. It could thus be said that the development of the military monastic order was a logical consequence of the vision of Christian knighthood proclaimed by Urban II at the council of Clermont. ${ }^{31}$

The appeal of this new institution can be seen from the fact that new orders sprang up on the Templar model in Outremer, Iberia and the Baltic region. Meanwhile the Order of the Hospital, originally a purely charitable and medical organisation, had by the 1160 s restructured itself to become a military order, while retaining its original hospitaller functions. A similar development occurred with the Order of St Mary of the Germans, founded as a hospitaller organisation during the Third Crusade, but which soon become a military order in which knight brethren were the dominant element. The first master of the Templars, a knight from Champagne named Hugh de Payns, came to Palestine some time after the First Crusade (probably in 1104) and indeed Templars, Hospitallers and Teutonic Knights rarely took part in large crusade expeditions. ${ }^{32}$ Rather, they usually entered their respective orders in Western Europe, and later travelled to the East by ship, where they were assigned postings. In the twelfth century the Templars and Hospitallers maintained significant numbers of knight brethren and sergeants who regularly fought alongside the forces of the secular rulers, but they made a wider contribution to the defence of Outremer. Since they derived revenues from their extensive estates in the West, they were able to finance the maintenance and construction of castles, especially in frontier areas. They also purchased fiefs and castles from secular nobles, many of whom had become impoverished as a result of having to pay ransoms, which meant that the orders acquired vassals of their own, who were obliged to perform military service. They also employed Turcopoles, who were under the command of a desig-

31 FOREY, A.J. (1985): "The Emergence of the Military Order in the Twelfth Century". Journal of Ecclesiastical History, n 36, pp. 175-195; BARBER, M. (1994): The New Knighthood: A History of the Order of the Temple. Cambridge, Cambridge University Press, pp. 1-37; CERRINI, S. (2001): "Le fondateur de l'ordre du Temple à ses frères: Hugues de Payns et le Sermo Christi militibus". BALARD, M., KEDAR, B.Z, and RILEY-SMITH, J. (eds), Dei gesta per Francos: Etudes sur les croisades dédiés à Jean Richard. Aldershot, Ashgate, pp. 99-1 10.

32 A notable exception was the Second Crusade, when a contingent of Templars accompanied the army of King Lovis VII of France (see Section 3.1 below). 
nated high officer called the turcopolier. ${ }^{33}$ When King Amalric of Jerusalem planned the invasion and annexation of Egypt in 1168-1171, the Hospitallers agreed to provide 500 knights and 500 Turcopoles in exchange for major territorial concessions in the Nile Delta and revenues elsewhere in Egypt. ${ }^{34}$ It is unlikely that the order could garrison its castles and undertake campaigns of this magnitude using only its own knight brethren, sergeants and Turcopoles, and there is considerable evidence that both Hospitallers and Templars employed different sorts of soldier who were not members of the orders. Some were mercenaries: knights, sergeants and even Turcopoles who were hired from outside. These contrasted with the volunteers known as milites ad terminum, recruited from lords and knights from the West who served for a limited period at their own expense. It is possible that these men arrived in the East in the periods between major crusade expeditions, and regarded service with one of the orders as the most promising opportunity to gain experience of combat against the Muslims. ${ }^{35}$

\section{The later Crusades}

\subsection{The Second Crusade (1 147-1 149)}

Thus, from the middle third of the twelfth century until the late thirteenth, the crusades were fought by several distinct categories of soldier: crusaders, that is volunteers from Western Europe who had taken vows to defend or liberate the Holy Land; the lords, knights, sergeants and Turcopoles in the

33 BARBER, The New Knighthood, pp. 166, 189; NICHOLSON, H. (2001): The Knights Hospitaller. Woodbridge, Boydell Press, pp. 21-23; FOREY, A.J. (1984): "The Militarisation of the Hospital of St John". Studia Monastica, n 26, pp. 75-89; RILEY-SMITH, J. (2012): The Knights Hospitaller in the Levant, c. 1070-1309. Basingstoke, Palgrave Macmillan, pp. 27-51; BURGTORF, J. (2006): "The Military Orders in the Crusader Principality of Antioch". CIGGAAR, K. and METCALF, M. (eds), East and West in the Medieval Mediterranean, I: Antioch from the Byzantine Reconquest until the End of the Crusader Principality. Leuven, Uitgeverij Peeters, pp. 217-246.

34 MURRAY, A.V. (2016): "The Grand Designs of Gilbert of Assailly: The Order of the Hospital in the Projected Conquest of Egypt by King Amalric of Jerusalem (1 168-1 169)". Ordines Militares: Yearbook for the Study of the Military Orders, n²0, pp. 7-24; MURRAY, A.V. (2016): "The Place of Egypt in the Military Strategy of the Crusades, 1099-1221". MYLOD, E.J., PERRY, G., SMITH, T.W. and VANDEBURIE, J. (eds.), The Fifth Crusade in Context: The Crusading Movement in the Early Thirteenth Century. Abingdon, Routledge, pp. 117-134.

35 FOREY, A.J. (2008): "Milites ad terminum in the Service of the Military Orders during the Twelfth and Thirteenth Centuries". UPTON-WARD, J. (ed.), The Military Orders, 4: On Land and by Sea. Aldershot, Ashgate, pp. 5-1 1; FOREY, A.J. (2016): "Paid Troops in the Service of the Military Orders during the Twelfth and Thirteenth Centuries". BOAS, A. (ed.), The Crusader World. London, Routledge, pp. 84-97. 
Frankish principalities of Outremer; the warrior monks and their service personnel in the military monastic orders; and mercenaries, who might have served any one of the other three groups who were wealthy enough to hire them. The involvement of each group varied considerably over time, and the character of crusades in particular began to change quite fundamentally from the later twelfth century onwards. Numerous land and sea expeditions continued to arrive in the East in the period between 1099 and 1147. The crusades of $1101,1122-1124$ and 1129 brought smaller numbers than in 1096-1099, and once they had arrived in Outremer they fought alongside seasoned local Frankish forces, who by this time had considerable experience in fighting their Turkish and Egyptian opponents. It was only with the so-called Second Crusade (1147-1149) that numbers of crusaders were comparable to those in Pope Urban's expedition.

While a combined force from northern Germany, the Low Countries and England sailed via Iberia, the main armies travelled by land, led Conrad III, king of Germany, and Louis VII, king of France. These two expeditions were bedevilled by problems similar to those which had been evident in the First Crusade, which were already evident in the period of preaching and recruitment. In 1146 a French Cistercian named Ralph inspired large numbers in the Rhineland, but their energies were largely directed into attacks on Jewish communities. He was eventually persuaded to desist and return to his monastery by Bernard of Clairvaux, who preached in a more moderate manner throughout south-western Germany, but it was noticeable that while large numbers of common people took the cross, those who were better off and experienced in warfare held back. When King Conrad took the cross at Easter 1147 in Würzburg along with numerous bishops, counts and nobles, large numbers of brigands and thieves turned up. This was not surprising. Bernard's preaching emphasised that sinners and criminals could redeem themselves by fighting for the cross, while a famine in 1146 meant that many peasants and agricultural labourers joined up in the hope of better prospects. Conor Kostick has convincingly argued that Conrad's army contained a large popular element which caused major problems during the passage through Byzantine territory with indiscriminate violence, looting and attacks on local populations, and ultimately forced Conrad to abandon his advance on the Anatolian plateau. ${ }^{36}$ This element was not only indisci-

36 PHILLIPS, J. (2007): The Second Crusade: Extending the Frontiers of Christendom. New Haven, Yale University Press, pp. 80-103; KOSTICK, C. (2010): "Social Unrest and the Failure of Conrad III's March through Anatolia, $1147^{\prime \prime}$. German History, n 28, pp. 125-142. 
plined; it had little real fighting experience. One of several sources which describe these events, the Annals of Pöhlde, describes the passage through Turkish-held territory, reporting that "the pedites were worn out by starvation and ignorant of wars". The Latin term pedites is normally translated as "footsoldiers", in distinction to mounted knights (milites), but this meaning makes little sense in this context; rather, pedites here is more likely to mean the large number of common people who were travelling on foot but had no military experience. ${ }^{37}$ Most of these refused to co-operate with the crusade leadership and became separated from the main force of knights. On 26 October 1147 they were overwhelmed by the army of Mas'ud, sultan of Rūm, and Conrad had little choice but to lead the survivors back to Constantinople.

We know less about the composition of the French army, but descriptions given by the chronicler suggest something similar. Unusually, Louis was accompanied by a contingent of Templars under their master, Everard of Barres, who acted as guides and divisional commanders during the crossing of Anatolia. Despite the support of such disciplined warriors, discipline left much to be desired. As Louis led his troops over the Kadmos mountain in southern Anatolia, a mass of common people lagged behind and began to be picked off by Turkish horse archers. Louis led his vanguard back to go to their aid, but the commoners, described as a "mob" (turba), failed to maintain resistance and fled, exposing themselves and the king's own troops to destruction. After this disaster Louis complained bitterly about the "unarmed mob" (inermem turbam) which had slowed down the passage and made food expensive. However, their numbers were swelled by those whom the chronicler Odo of Deuil neatly describes as "those whom nature or fortune had made into footsoldiers" (Illi ... quos natura fecerat pedites vel fortuna), explaining that many of the nobles were marching not with the cavalry, but among the mob in "an unaccustomed manner" (multi enim nobiles rebus preditis vel expensis more insolito ibant in turba). The combination of Turkish attacks and privation meant that many horses died of hunger, were killed in fighting, or were slaughtered for food, and many who had lost their mounts threw away much of their equipment rather carry it in foot. ${ }^{38}$ When the army reached the coast, those who could afford it were desperate to buy fresh horses, as this would have most readily restored their fighting

37 'Annales Palidenses', in Monumenta Germaniae Historica: Scriptores, n 16 (1869), pp. 82-83: pedites inedia fatigati nec bellorum gnari ideoque minus cauti periculorum.

38 Odo of Deuil, De profectione Ludovici VIl in orientem, ed. and trans. V.G. BERRY (New York, Columbia University Press, 1948), pp. $114-135$ (here 124, 130). English translations by the present author. 
ability, but mounts were practically unobtainable. According to Odo, the French barons lamented to their king, saying "since they have cast their arms aside, all of the common knights in your army have been reduced to foot soldiers ... and the same fate has befallen many of the more noble ones". ${ }^{39}$ This entire dialogue is clearly a literary construction, but it encapsulates how the status of knights and nobles could be reduced to the level of commoners through the loss of horses and equipment, in much the same way as had occurred during the expeditions of 1096-1099. The military defeats suffered by both German and French armies in Asia Minor not only reduced the numbers that they were able to bring to the Holy Land; they also meant that these disparate forces were never able to develop the type of cohesion that was achieved by the First Crusade armies as they marched south from Antioch.

\subsection{From Land Campaigns to Sea Voyages}

After 1149 there was a significant change in the composition of crusade expeditions. By and large, crusade expeditions came to comprise a far higher proportion of crusaders who could be regarded as professionals, that is nobles, knights and footsoldiers and support personnel such as grooms or squires. The leadership were keen to exclude the indigent, who would put a strain on financial and alimentary resources and had little fighting ability, as previous experience had shown. It was never possible to exclude civilians entirely. For one thing, clerics were invariably present to act as advisors to secular leaders and also to provide for the spiritual welfare of the troops. Some women were allowed to participate carry out duties such as laundry and delousing. ${ }^{40}$ However, those expeditions which actually reached the East did not contain anything like the large popular elements that were found in 1096 and 1147. When preaching did produce a large response from the common people, these usually combined into disorganised and undisciplined mobs which were shunned by knights and nobles, as was the case with the so-called Pastores who received considerable popular support in France and western Germany in 1251 and 1320.

There were two main organisational and logistic factors which helped bring about this change. The first was the introduction of dedicated crusade taxation. Between 1166 and 1199 the kings of France and England and the

39 Odo of Deuil, De profectione Ludovici VII in orientem, p. 130: Omnes vestri exercitus gregarii milites his diebus armis proiectis pedites sunt effecti, et cum eis de nobilioribus multi. English translation by Berry (p. 131).

40 TYERMAN, How to Plan a Crusade, p. 249. 
popes declared various taxes on incomes and property which were to be used for the defence or liberation of the Holy Land. Collection methods varied, but in general the proceeds went to kings or other nobles who were in the process of organising crusades. This meant that they were able to divert funds to their own followers and others whose skills and equipment would be of the greatest use on campaign.

An equally important matter was a shift towards seaborne expeditions. Up to the time of the Third Crusade (1 189-1 192) some smaller expeditions had travelled to Palestine by sea, but larger armies (which we could define as those numbering thousands) all took overland routes, proceeding either down the Italian peninsula with a short crossing of the Adriatic to link with the Byzantine road system, or along the Danube and through the Balkans. From Constantinople various routes were available through Asia Minor, although as the examples from the Second Crusade show, these all carried the risk of privation and attacks from the Turkish powers of Anatolia and nomadic Türkmen tribesmen. ${ }^{41} \mathrm{~A}$ turning point came about at the time of the Third Crusade (1 189-1 192), called in response to the defeat of King Guy of Jerusalem by Saladin at Hattin and the subsequent loss of Jerusalem and most of the Holy land in 1187 . Frederick Barbarossa, Holy Roman emperor, assembled an army at Regensburg and marched along the traditional route through the Balkans. This had a logistic advantage in that much of the army's baggage could by transported by boat on the Danube as far as Byzantine territory. Frederick may also have been influenced by his own experience, having accompanied his uncle Conrad III by land in the Second Crusade. However, the armies of Richard the Lionheart of England and Philip Augustus of France covered the greater part of their journeys by sea, and all subsequent expeditions to the Levant were carried on fleets. This shift was brought about by technological possibilities as well as logistical necessity. Developments in shipbuilding and navigation made it possibly to transport horses over long distances by sea, something which had been quite impractical around $1100.4^{42}$ The transport of knights and their horses meant

41 MURRAY, A.V. (2012): "Roads, Bridges and Shipping in the Passage of Crusade Armies by Overland Routes to the Bosporus, 1096-1 190". BLASCHITZ, G., HOLZNER-TOBISCH, K., and KÜHTREIBER, Th. (eds.), Die Vielschichtigkeit der Straßen: Kontinuität und Wandel in Mittelalter und früher Neuzeit. Wien, Verlag der Österreichischen Akademie der Wissenschaften, pp. 183207.

42 PRYOR, J.H. (1982): "Transportation of Horses by Sea during the Era of the Crusades: Eighth Century to 1285 A.D.". Mariner's Mirror, n 68, pp. 9-27, 103-125; PRYOR, J.H. (2015): "A Medieval Mediterranean Maritime Revolution: Crusading by Sea, ca. 1096-1204". CARLSON, D.N., LEIDWANGER, J., and KAMPBELL, S.M. (eds.), Maritime Studies in the Wake of the Byzantine Shipwreck at Yassıada, Turkey. College Station, Texas A\&M University Press, pp. 174-188. 
that large quantities of equipment could also be carried. Thus Richard the Lionheart arranged for many thousands of horseshoes to be supplied to his troops; it would have been difficult to carry these by land, but the capacity of his ships made it possible..$^{43}$ All of these factors combined to produce the conditions for a more professional army. The final consideration was that with ships under the command of royal officers it was now possible to physically prevent undesirables from taking part.

The dimensions of such organisational changes can be seen in the logistic arrangements contracted for the Fourth Crusade (1201-1204). While previous expeditions had been directed to the Holy Land, the leaders who planned the crusade in the years 1199-1201 decided to make a major attack against Egypt, the centre of the power of the Ayyūbid dynasty (Saladin's successors). The aim was to strike a major blow which would force the Ayyūbid sultan to surrender Jerusalem and other territories in a negotiated peace. Representatives of the crusade leadership negotiated a treaty with the republic of Venice, whose doge and counsellors agreed to provide transport for the entire crusade army and to supplement this with additional ships and naval forces. The treaty specified that transport would be provided for 4500 "well-armed knights" (milites bene armatos) and the same number of horses, 9000 squires (scutiferos), and 20,000 "well-armed foot soldiers" (pedites bene armatos). ${ }^{44}$ These Latin descriptions correspond to the French terms used in the account of the treaty given by the French chronicler Villehardouin: chevaliers, escuiers, and serjanz a pié. ${ }^{45}$ These categories suggest a completely professional army. Since each knight was allowed two scutiferi or escuiers, it is tempting to assume that one was in charge of the knight's horse while the other was to look after his equipment and help him arm. The term pedites bene armatos or serianz a pié undoubtedly meant that these were expected to be experienced soldiers with good quality equipment, corresponding to the foot sergeants employed in the armies of Outremer and the military orders, rather than simply untrained pilgrims on foot. They included specialists such as crossbowmen, who fought well at

43 TYERMAN, How to Plan a Crusade, pp. 263-265.

44 Urkunden zur älteren Handels- und Staatsgeschichte der Republik Venedig: mit besonderer Beziehung auf Byzanz und die Levante vom neunten bis zum Ausgang des fünfzehnten Jahrhunderts, ed. G.L.F. TAFEL and G. THOMAS, 3 vols (Wien, Hof- und Staatsdruckerei, 1856-1857), vol. 1, pp. 365-366.

45 Villehardouin, La Conquête de Constantinople, ed. and trans. E. FARAL, 2 vols (Paris, Les Belles Lettres, 1961), vol. 1, pp. 22-25. 
Constantinople, but overall the crusaders who assembled at Venice were far short of the numbers agreed in the treaty, and many were not of the quality envisaged in it. Robert of Clari, a French crusader, describes a category he calls the "common people" (menue gent) who nevertheless had to fight. In the first assault on Constantinople (July 1203), the commanders ordered up all the grooms and cooks in the army and kitted them out with improvised arms and armour; despite the inferior quality of this equipment, they were encouraged that these temporary soldiers were so "ugly and hideous that the common foot soldiers of the emperor, who were in front of the walls, had great fear and terror when they saw them". ${ }^{46}$ Clari also tells of clerics who took part in the fighting. A priest, Aleaumes de Clari, had either come with, or acquired a horse and hauberk; since he had fought like a knight, he argued that he was entitled to a knight's share in the booty after the final assault in April 1204. ${ }^{47}$

The failure of the crusade occurred because insufficient numbers arrived at Venice by the agreed departure date. Since the reduced army could not raise the agreed costs of transport, it had no choice but to follow Venetian direction, a decision which ultimately led to the diversion of the crusade to Constantinople. However, the process of planning and recruitment show that a century after Pope Urban's appeal, the business of crusading was expected to succeed only with personnel who could be described as professionals.

\section{Conclusions}

The idealistic intentions of the papacy to liberate (and later to defend) the Holy Land would require the whole-hearted participation of the traditional military classes of Western Europe. This was why at the Council of Clermont Pope Urban II appealed to the class of knights. Yet the definition of the crusade as a pilgrimage, with unheard of spiritual rewards, meant that all sections of the population were encouraged to take part, most of whom had

46 Robert de Clari, La Conquête de Constantinople, ed. P. LAUER (Paris, Honoré Champion, 1974), p. 46: Et aprés prist on tous les garchons qui les chevax gardoient, et tous les cuisiniers qui armes peurent porter; si les fist on trestous armer et de keutes pointes et de peniax et de pos de coivre et de poletes et de pestiaux, si k'il estoient si lait et si hideus qie le menue gent a pié l'empereur, qui estoient par dehors les murs, en eurent grant peur et grant hisde, quant ils les virent. Translation from: Robert of Clari, The Conquest of Constantinople (New York, Columbia University Press, 1936), p. 72.

47 Robert de Clari, La Conquête de Constantinople, p. 96. 
little military skill or experience, and often insufficient funds or equipment to function effectively through the rigours of the journey. The dichotomy between military professionals and elites on the one hand, and popular elements on the other constituted the main factor which threatened the success of crusading during this period, even more than political rivalries based on national or feudo-vassalic allegiances. This situation only began to change from 1189 onwards. The shift away from land-based to seaborne expeditions, although undertaken primarily for logistical reasons, allowed the organisers to exclude popular elements in favour of trained professional soldiers. However, the concentration on professionalism brought about a necessity for upfront funding on a hitherto unimagined scale, which produced unforecast problems in the crusade originally intended to be directed against Egypt in 1201.

\section{BibLIOGRAPHY}

\section{Sources}

Albert of Aachen, Historia lerosolimitana: History of the Journey to Jerusalem, ed. and trans. S. B. EDGINGTON (Oxford: Oxford University Press, 2007).

'Annales Palidenses', in Monumenta Germaniae Historica: Scriptores 16 (1869), pp. 48-98.

Chronicles of the First Crusade, 1096-1099, ed. C. TYERMAN (London, Penguin, 2004).

Gilbert of Mons, Chronicle of Hainaut, trans. L. NAPRAN (Woodbridge, Boydell Press, 2005).

Guillaume de Tyre, Chronique, ed. R.B.C. HUYGENS, Corpus Christianorum Continuatio Mediaevalis 63-63A, 2 vols (Turnhout: Brepols, 1986), p. 790.

MAYER, H.E. (ed.), Die Urkunden der lateinischen Könige von Jerusalem, 4 vols (Hannover: Hahnsche Buchhandlung, 2010), 1, no. 298.

Odo of Deuil, De profectione Ludovici VII in orientem, ed. and trans. V.G. BERRY (New York, Columbia University Press, 1948).

Robert de Clari, La Conquête de Constantinople, ed. P. LAUER (Paris, Honoré Champion, 1974).

Robert of Clari, The Conquest of Constantinople (New York: Columbia University Press, 1936).

RÖHRICHT, R. (ed.), Regesta Regni Hierosolymitani, 2 vols (Innsbruck: Wagner, 1893-1904), 
Urkunden zur älteren Handels- und Staatsgeschichte der Republik Venedig: mit besonderer Beziehung auf Byzanz und die Levante vom neunten bis zum Ausgang des fünfzehnten Jahrhunderts, ed. G.L.F. TAFEL and G. THOMAS, 3 vols (Wien: Hof- und Staatsdruckerei, 1856-1857).

Villehardouin, La Conquête de Constantinople, ed. and trans. E. FARAL, 2 vols (Paris: Les Belles Lettres, 1961).

Walter the Chancellor, Galterii Cancelarii Bella Antiochena, ed. H. HAGENMEYER (Innsbruck: Wagner, 1896).

\section{Literature}

BARBER, M. (1994), The New Knighthood: A History of the Order of the Temple. Cambridge, Cambridge University Press.

BIRKENMEIER, J. (2002): The Development of the Komnenian Army, 1081 1 180. Leiden, Brill, pp. 77-158

BUMKE, Joachim (1982): The Concept of Knighthood in the Middle Ages. New York, AMS Press.

BURGTORF, J. (2006): "The Military Orders in the Crusader Principality of Antioch". In: CIGGAAR, K. and METCALF, M. (eds), East and West in the Medieval Mediterranean, I: Antioch from the Byzantine Reconquest until the End of the Crusader Principality. Leuven, Uitgeverij Peeters, pp. 217-246.

CERRINI, S. (2001): "Le fondateur de l'ordre du Temple à ses frères: Hugues de Payns et le Sermo Christi militibus". In: BALARD, M., KEDAR, B.Z, and RILEY-SMITH, J. (eds), Dei gesta per Francos: Etudes sur les croisades dédiés à Jean Richard. Aldershot, Ashgate, pp. 99-110.

CONSTABLE, G. (1982): "The Financing of the Crusades in the Twelfth Century". In: KEDAR, B.Z., MAYER, H.E. and SMAIL, R.C. (eds), Outremer: Studies in the History of the Crusading Kingdom of Jerusalem. Jerusalem, Yad Izhak Ben-Zvi Institute, pp. 64-88

EDBURY, P.W. (1997): John of Ibelin and the Kingdom of Jerusalem. Woodbridge, Boydell.

FLORI, J. (1998): Chevaliers et chevalerie au Moyen Age, Paris, Hachette. FLORI, J. (1999): Pierre l'Ermite et la Première Croisade. Paris, Fayard.

FOREY, A.J. (1984): "The Militarisation of the Hospital of St John", Studia Monastica $\mathrm{n}^{\circ}$ 26, pp. 75-89.

FOREY, A.J. (1985): "The Emergence of the Military Order in the Twelfth Century", Journal of Ecclesiastical History n ${ }^{\circ} 36, \mathrm{pp}$. 175-195.

FOREY, A.J. (2008): "Milites ad terminum in the Service of the Military Orders during the Twelfth and Thirteenth Centuries". In: UPTON-WARD, J. 
(ed.), The Military Orders, 4: On Land and by Sea. Aldershot, Ashgate, pp. 5-11.

FOREY, A.J. (2016): "Paid Troops in the Service of the Military Orders during the Twelfth and Thirteenth Centuries". In: BOAS, A., The Crusader World. London: Routledge, pp. 84-97.

FRANCE, J. (1994): Victory in the East: A Military History of the First Crusade. Cambridge, Cambridge University Press.

FRANCE, J. (1999): Western Warfare in the Age of the Crusades, 10001300. London, UCL.

FRANCE, J. (2000): "Crusading Warfare and its Adaptation to Eastern Conditions in the Twelfth Century". Mediterranean Historical Review $n^{\circ} 15$, pp. 49-56.

FRANCE, J. (2005): "Crusading Warfare". In: NICHOLSON, H. (ed.) Palgrave Advances in the Crusades. Basingstoke, Palgrave Macmillan

FRANCE, J. (2006): "Thinking about Crusader Strategy". In: CHRISTIE, N. and YAZIGI, M. (eds.), Noble Ideals and Bloody Realities: Warfare in the Middle Ages. Leiden, Brill, pp. 75-96

FRANCE, J. (2011): "Warfare in the Mediterranean Region in the Age of the Crusades, 1095-1291: A Clash of Contrasts". In: KOSTICK, C. (ed.), The Crusades and the Near East. Abingdon: Routledge, pp. 9-26

FRANCE, J. (ed.) (2008), Mercenaries and Paid Men: The Mercenary Identity in the Middle Ages, Leiden: Brill.

HILLENBRAND, C. (1999): The Crusades: Islamic Perspectives. Edinburgh, Edinburgh University Press.

KOSTICK, C. (2008): The Social Structure of the First Crusade, Leiden, Brill. KOSTICK, C. (2010): "Social Unrest and the Failure of Conrad III's March through Anatolia, 1147", German History n 28, pp. 125-142.

KOSTICK, C. (2013): "Courage and Cowardice in the First Crusade, 10961099", War in History n ${ }^{\circ} 20$, pp. 32-49

MÖHRING, H. (1992): Graf Emicho und die Judenverfolgungen von 1096", Rheinische Vierteljahrsblätter n 56, pp. 97-111.

MURRAY, A.V. (2009): "Norman Settlement in the Latin Kingdom of Jerusalem, 1099-1131", Archivio Normanno-Svevo n 1 for 2008 (2009), 61-85.

MURRAY, A.V. (1992): "The Army of Godfrey of Bouillon, 1096-1099: Structure and Dynamics of a Contingent on the First Crusade", Revue Belge de Philologie et d'Histoire $\mathrm{n}^{\circ}$ 70, pp. 301-29.

MURRAY, A.V. (2006): "Money and Logistics in the Armies of the First Cru- 
sade: Coinage, Bullion, Service and Supply, 1096-99". In: PRYOR, J. H. (ed.), Logistics of Warfare in the Age of the Crusades. Aldershot, Ashgate, pp. 229-49.

MURRAY, A.V. (2008): "The Origin of Money-Fiefs in the Latin Kingdom of Jerusalem". In: FRANCE, J. (ed.), Mercenaries and Paid Men: The Mercenary Identity in the Middle Ages. Leiden, Brill, pp. 275-286.

MURRAY, A.V. (2012): "Roads, Bridges and Shipping in the Passage of Crusade Armies by Overland Routes to the Bosporus, 1096-1190". In: BLASCHITZ, G., HOLZNER-TOBISCH, K., and KÜHTREIBER, Th. (eds.), Die Vielschichtigkeit der Straßen: Kontinuität und Wandel in Mittelalter und früher Neuzeit. Wien, Verlag der Österreichischen Akademie der Wissenschaften, pp. 183-207.

MURRAY, A.V. (2012): "Sex, Death and the Problem of Single Women in the Armies of the First Crusade'. In: GERTWAGEN, R. and JEFFREYS, E. (eds.), Shipping, Trade and Crusade in the Medieval Mediterranean: Studies in Honour of John Pryor. Farnham, Ashgate, pp. 255-270.

MURRAY, A.V. (2014): "The Siege and Capture of Jerusalem in Western Narrative Sources of the First Crusade". In: EDGINGTON, S., and GARCÍA-GUIJARRO, L. (eds.), Jerusalem the Golden: The Origins and Impact of the First Crusade. Turnhout, Brepols, pp. 191-215.

MURRAY, A.V. (2015): "The Enemy Within: Bohemond, Byzantium and the Subversion of the First Crusade". In: HURLOCK, K. and OLDFIELD, P. (eds.), Crusading and Pilgrimage in the Norman World. Woodbridge, Boydell \& Brewer, pp. $31-47$.

MURRAY, A.V. (2016): "The Grand Designs of Gilbert of Assailly: The Order of the Hospital in the Projected Conquest of Egypt by King Amalric of Jerusalem (1 168-1 169)", Ordines Militares: Yearbook for the Study of the Military Orders 20, pp. 7-24.

MURRAY, A.V. (2016): "The Place of Egypt in the Military Strategy of the Crusades, 1099-1221". In: MYLOD, E.J., PERRY, G., SMITH, T.W. and VANDEBURIE, J. (eds.), The Fifth Crusade in Context: The Crusading Movement in the Early Thirteenth Century, Abingdon, Routledge, pp. 117-134.

MURRAY, A.V. (2017): "A Race against Time - A Fight to the Death: Combatants and Civilians in the Siege and Capture of Jerusalem". In: DOWDALL, A. and HOME, J. (eds.) Civilians under Siege from Sarajevo to Troy, Basingstoke, Palgrave Macmillan, forthcoming.

NICHOLSON, H. (2001): The Knights Hospitaller, Woodbridge, Boydell Press. PHILLIPS, J. (2007): The Second Crusade: Extending the Frontiers of Christendom. New Haven, Yale University Press, pp. 80-103. 
PORGES, W. (1946), "The Clergy, the Poor and the Non-Combatants on the First Crusade", Speculum n ${ }^{\circ} 21$, pp. 1-23.

PRYOR, J. (1992): Geography, Technology and War: Studies in the Maritime History of the Mediterranean, 649-1571. Cambridge, Cambridge University Press.

PRYOR, J. (ed.) (2006); Logistics of Warfare in the Age of the Crusades. Aldershot, Ashgate.

PRYOR, J.H. (1982): "Transportation of Horses by Sea during the Era of the Crusades: Eighth Century to 1285 A.D.", Mariner's Mirror n ${ }^{\circ}$ 68, pp. 9-27, 103-125.

PRYOR, J.H. (2015): "A Medieval Mediterranean Maritime Revolution: Crusading by Sea, ca. 1096-1204". In: CARLSON, D.N., LEIDWANGER, J., and KAMPBELL, S.M. (eds.), Maritime Studies in the Wake of the Byzantine Shipwreck at Yassıada, Turkey. College Station, Texas A\&M University Press, pp. 174-188.

RICHARD, J. (1986): "Les Turcoples au service des royaumes de Jérusalem et de Chypre: Musulmans convertis ou chrétiens orientaux?", Revue des études islamiques $\mathrm{n}^{\circ}$ 54, pp. 259-270.

RICHARD, J. (1989): "La noblesse de Terre Sainte (1097-1 187", Arquivos do Centro cultural português $n^{\circ} 26$, pp. 321-336

RILEY-SMITH, J. (1967): The Knights Hospitaller in the Levant, c. 10701309, Basingstoke, Palgrave Macmillan, pp. 27-51

RILEY-SMITH, J. (1986): The First Crusade and the Idea of Crusading. London, Athlone.

RILEY-SMITH, J. (1995): "Early Crusaders and the Costs of Crusading, 1095-1 130". In: GOODICH, M., MENACHE, S. and SCHEIN, S. (eds.). Cross Cultural Convergences in the Crusader Period. New York, Peter Lang, pp. 237-258.

RILEY-SMITH, J. (1997): The First Crusaders, 1095-1 131. Cambridge, Cambridge University Press.

SALIBI, K.S. (1957): "The Maronites of Lebanon under Frankish and Mamluk Rule (1099-1516)", Arabica n 4, pp. 280-303.

SHEPARD, J. (1997): "Cross-Purposes: Alexius Comnenus and the First Crusade". In: PHILLIPS, J. (ed.): The First Crusade: Origins and Impact, Manchester, Manchester University Press, pp. 107-129.

SMAIL, R.C. (1995): Crusading Warfare, 1097-1193, 2nd edn. ed. C. MARSHAL. Cambridge, Cambridge University Press.

TYERMAN, C. (2015): How to Plan a Crusade: Reason and Religious War in the High Middle Ages, London, Allen Lane. 